\title{
Reformy w polskim szkolnictwie wyższym po 1990 r. w świetle nauki o polityce publicznej
}

\begin{abstract}
Streszczenie
Artykuł jest propozycją bilansu procesów reformowania szkolnictwa wyższego w Polsce w latach 1990-2015 i 2016-2018 (kiedy przygotowywano projekt tzw. Ustawy 2.0) oraz wynikającej z tych analiz oceny rodzimej „sztuki reformowania”.

W efekcie przyjęcia perspektywy nauk o polityce publicznej w centrum uwagi autorki znalazły się kwestie wchodzące w zakres formułowania polityki publicznej, tj. polityki rozwoju i programowania strategicznego, projektowania prawa i towarzyszących mu konsultacji społecznych. Ponadto artykuł omawia trzy dokonane próby i jedną obecnie projektowaną próbę reformowania szkolnictwa wyższego w kontekście zasad ekonomii politycznej reform uznawanych na świecie za wzorzec.

Długi, bo niemal 30-letni okres objęty analizami umożliwił na ich podstawie wnioski dotyczące ewolucji polityki szkolnictwa wyższego uwypuklające problem jej jakości (standardów) jako polityki publicznej.

Główna teza, zweryfikowana z pomocą koncepcji ekonomii politycznej reform, dotyczy widocznego uczenia się reguł tworzenia polityki publicznej przez decydentów w trakcie kolejnych reform szkolnictwa wyższego w Polsce (jest to jednak uczenie się dość wolne i niedostateczne albo nieefektywne).
\end{abstract}

Słowa kluczowe: polityka publiczna, polityka szkolnictwa wyższego, reforma szkolnictwa wyższego, prawo o szkolnictwie wyższym

\section{Higher Education Policy and Its Reforms in Poland in View of the Public Policy Science}

\begin{abstract}
This paper attempts to present a review of higher education reform processes in Poland in 1990-2015 and 2016-2018 (when a draft of the so-called Act 2.0 was prepared) and an assessment of the domestic "art of reforms".
\end{abstract}


As the author has adopted the perspective of the public policy science, she focuses on issues of public policy making, i.e. the development and strategic programming policy, drafting legislation, and accompanying public consultations. Furthermore, the paper discusses three past and one current attempt to reform higher education in the context of the political economy of reforms that are globally perceived as a benchmark.

The long, nearly 30 -year period covered by the paper's analyses allowed the author to draw conclusions with regard to the evolution of higher education policy, highlighting the problem of its quality (standards) as a public policy.

Keywords: public policy, higher education policy, higher education reform, higher education law

Nie wchodząc w zawiłości definicyjne związane z terminem „polityka publiczna” (public policy), warto wskazać przyjęte w niniejszym tekście jego znaczenie. Chodzi mianowicie o „zracjonalizowane działania i programy publiczne, które posiadają zamierzoną strukturę ich projektowania i wykonywania oraz oparte są na względnie zobiektywizowanej wiedzy analitycznej” (Zybała, 2013: 41). Działania te przypisuje się podmiotom, które wchodzą w zakres pojęcia rządu - wąsko bądź szerzej rozumianego, tj. ministrom i premierowi, a nawet partii rządzącej (Szarfenberg, 2016: 48). $\mathrm{W}$ tak zarysowanych ramach konceptualnych z całą pewnością umiejscowić można analizy działań publicznych/ministerialnych (reform) w różnych rodzajach polityki (sektorowych i horyzontalnych), w tym w polityce szkolnictwa wyższego. Zwłaszcza że tradycyjna dyscyplina - nauka o polityce - przedstawia kontekst poszczególnych gałęzi polityki sektorowej, natomiast nauki o polityce publicznej zajmują się przede wszystkim badaniem działalności organów władz publicznych w zakresie polityki sektorowej, ich funkcjami, procesami decyzyjnymi oraz implementacją decyzji (Fundacja Rektorów Polskich, 2012).

Co ciekawe, to właśnie ze środowiska związanego z polityką wobec nauki i szkolnictwa wyższego wyszła w 2011 r. decyzja o ustanowieniu w Polsce nowej dyscypliny: nauki o polityce publicznej (Szarfenberg, 2013: 26). Do tego czasu obszar badań szkolnictwa wyższego (podobnie jak badań oświatowych, badań nad polityką naukową, badań nad polityką społeczną czy badań nad polityką cyfryzacji) nie znajdował właściwego dla siebie miejsca w strukturze dyscyplin naukowych obowiązującej w Polsce ${ }^{1}$. Wyodrębnienie nowej dyscypliny pozwoliło politykom sektorowym znaleźć dobre zakotwiczenie w nauce.

1 W związku z projektowanym nowym Prawem o szkolnictwie wyższym i nauce (tzw. Ustawą 2.0 - Konstytucją dla nauki) planowana jest nowa klasyfikacja dziedzin i dyscyplin inspirowana klasyfikacją 
„Pojawienie się nowej dyscypliny umożliwia integrowanie i konsolidowanie się środowiska badaczy analizujących poszczególne polityki sektorowe, dzięki czemu realizowana w kraju polityka publiczna zyskuje bardziej dostępne i merytorycznie głębsze zaplecze naukowe” (Woźnicki, 2015: 12).

Zgodnie z wykazem proponowanych specjalności naukowych wskazywanych przez Jerzego Woźnickiego (2012) badania nad szkolnictwem wyższym (wraz z badaniami oświatowymi) miały tworzyć specjalizację w ramach specjalności - polityka rozwoju społeczeństwa wiedzy, obejmującej polityki wzrostu kapitału intelektualnego, pomnażania dorobku kulturowego oraz rozwoju sektora wiedzy. Pomysłodawcy tego wykazu, uwzględniając interdyscyplinarność problematyki, zidentyfikowali powiązania $z$ innymi dyscyplinami: pedagogiką (badania nad polityką oświatową), naukami o zarządzaniu, filozofią, psychologią, socjologią i ekonomią (Woźnicki, 2012: 142). Owa interdyscyplinarność jest warunkiem sine qua non badań nad szkolnictwem wyższym (higher education research), obejmujących również badania nad polityką szkolnictwa wyższego, prowadzonych przez socjologów. Na gruncie samej socjologii, w przypadku analizy polityki publicznej, konieczna jest wewnętrzna interdyscyplinarność pozwalająca na sprawne wykorzystanie dorobku m.in. socjologii edukacji, socjologii sfery publicznej, socjologii polityki czy socjologii prawa (Dziedziczak-Foltyn, 2017: 14-20). Reasumując, opracowywanie i wprowadzanie przez władze publiczne (resort odpowiedzialny za szkolnictwo wyższe) intencjonalnych, celowych i sterowanych zmian, szczególnie prawnych i finansowych, jest naturalnym za granicą przedmiotem studiów nad polityką szkolnictwa wyższego i nauki, czyli polityką publiczną (Antonowicz, 2015: 67, 70). Wpisuje się ono w mutlimodalne związki pomiędzy badaniami szkolnictwa wyższego (w tym socjologiczne) i polityką publiczną w tym sektorze (Dziedziczak-Foltyn, 2017: 19).

Andrzej Zybała, pisząc o wyłanianiu się w Polsce polityki publicznej jako dyscypliny naukowej i jako usystematyzowanej aktywności publicznej w państwie, podkreśla brak zaawansowania teoretycznego i empirycznego w badaniach polityki publicznej. Reprezentanci politologii, ekonomii, socjologii czy nauk o administracji zajmujący się polityką publiczną najczęściej sprowadzają swoje badania do opisu strony formalnoprawnej konstrukcji działań publicznych, czyli omawiają prawodawstwo dotyczące danej polityki publicznej. Autor wskazuje na brak analiz ukierunkowanych

OECD. Ministerstwo Nauki i Szkolnictwa Wyższego zamierza ograniczyć liczbę dyscyplin ze 102 do około 40. Pojawia się w związku z tym pytanie o dalsze losy i szanse na rozwój nowej dyscypliny - nauki o polityce publicznej po 2021 r., gdy nowa klasyfikacja stanie się podstawą uprawiania nauki w Polsce. 
na interesariuszy, agendy, instytucje, dynamikę działań, procesy partycypacji, debaty, wykorzystanie wiedzy czy wykonalność (Zybała, 2013: 104-106).

W artykule zaprezentowane są najważniejsze wnioski wynikające bezpośrednio z przeglądu aktywności strategicznej i legislacyjnej państwa w latach 1990-2018 wobec obszaru szkolnictwa wyższego, która stanowi ważny element cyklu polityki publicznej - fazy jej formułowania, a dokładnie fazy wypracowania koncepcji reformy. Stanowią one jednak fragment szerszego badania opisanego w książce Reforma szkolnictwa wyższego $w$ debacie publicznej w Polsce. Bilans dyskusji o uniwersytetach (1990-2015). Jest to studium debaty publicznej wokół reformowania szkolnictwa wyższego w trakcie ćwierćwiecza, przeprowadzone niejako z dwóch perspektyw: socjologicznej analizy dyskursu publicznego (analiza debaty publicznej w trzech wymiarach: naukowym, strategiczno-legislacyjnym i publicystycznym) oraz perspektywy nauk o polityce publicznej (analiza agendy, deliberacji i debaty) (Dziedziczak-Foltyn, 2017).

\section{Reformowanie szkolnictwa wyższego na tle działań państwa}

Usytuowanie reform szkolnictwa wyższego w gąszczu pojęć typowych dla nauk o polityce, w tym nauk o polityce publicznej, było niezbędnym zabiegiem analitycznym mającym na celu konceptualizację „sztuki reformowania” (zdolności do reformowania), która legła u podstaw wspomnianego studium reformy. Ze względu na położony w badaniach akcent na deliberację i proces konsultacyjny stanowi ona odpowiednik pojęcia reform capacity wykorzystywanego w odniesieniu do polityki publicznej, ze względu na zdolność decydentów do dzielenia się władzą i uwzględniania różnych grup interesów (Lindvall, 2017). W szerszym ujęciu chodzi o zdolność do projektowania i wykonywania polityki publicznej, czyli jej jakość - artykułowaną jako oparte na merytorycznych przesłankach działania publiczne z uwzględnieniem szerokiej deliberacji nad problemami publicznymi (roli ekspertów i interesariuszy).

Za punkt wyjścia w analizie działań państwa w zakresie polityki publicznej przyjęto sprzężenie pomiędzy politykami sektorowymi a horyzontalnymi i umiejscowienie polityki rozwoju w strukturze polityki publicznej w Polsce (Zybała, 2013: 174-175). Drugim znaczącym czynnikiem wpływającym na sposób uprawiania polityki publicznej, pośrednio zaś na kształt reform, były procesy zarządzania publicznego - rozumianego jako system decydowania w sprawach publicznych. W związku z tym w badaniach reform szkolnictwa wyższego wyklarowała się optyka cyklu polityki publicznej z wyodrębnieniem fazy formułowania polityki, przy założeniu o dominującym w Polsce modelu publicznego zarządzania poprzez legislację (Ibidem: 29, 
33-37). Pozwoliła ona na kompleksowe uchwycenie szerszych uwarunkowań działań państwa w zakresie projektowania prawa dotyczącego obszaru szkolnictwa wyższego (rysunek 1).

\begin{tabular}{|c|c|c|c|c|}
\hline \multirow{6}{*}{ 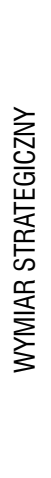 } & \multirow{6}{*}{ 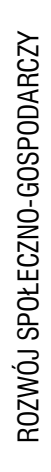 } & \multicolumn{3}{|c|}{ WYMIAR POLITYCZNY } \\
\hline & & \multicolumn{3}{|c|}{ SPRAWNE PAŃSTWO } \\
\hline & & 崖至 & \multicolumn{2}{|c|}{ RZĄDZENIE PUBLICZNE (PUBLIC GOVERNANCE) } \\
\hline & & 蛋交 & \multicolumn{2}{|c|}{$\begin{array}{c}\text { ZARZACZZANIE PUBLICZNE } \\
\text { (PUBLIC MANAGEMENT) }\end{array}$} \\
\hline & & $\stackrel{2}{\$}$ & $\begin{array}{l}\text { POLITYKA PUBLICZNA } \\
\text { (PUBLIC POLICY) }\end{array}$ & $\begin{array}{c}\text { Strategia rozwoju } \\
\text { szkolnictwa wyższego }\end{array}$ \\
\hline & & 옹요 & PRAWO & Prawo o szkolnictwie wyższym \\
\hline
\end{tabular}

Rysunek 1. Reformowanie szkolnictwa wyższego a nadrzędne cele państwa

Źródło: opracowanie własne na podstawie Dziedziczak-Foltyn (2017: 5).

Powyższe zestawienie (o charakterze modelu idealnego) dotyczy dwóch kluczowych wymiarów działania państwa: strategicznego (w kontekście imperatywu rozwoju społeczno-gospodarczego) (Dziedziczak-Foltyn, 2011: 88-106) i politycznego (w rozumieniu dobrej jakości rządzenia) (Wilkin, 2013). Jest próbą uporządkowania koniecznej terminologii i aparatu pojęciowego w celu ukazania wzajemnych powiązań i sprzężeń pomiędzy tymi wymiarami. Nie ilustruje ono rzeczywistej realizacji polityki szkolnictwa wyższego w Polsce, która odbiegała od optymalnego schematu reformowania polegającego m.in. na opracowaniu w pierwszej kolejności strategii rozwoju, a następnie zaprojektowaniu prawa mającego służyć jej realizacji. W prezentowanym modelu prawo o szkolnictwie wyższym (PoSW) ma być efektem zarówno orientacji strategicznej na rozwój społeczno-gospodarczy, w którym szkolnictwo wyższe jest współautorem i współaktorem skoku cywilizacyjnego w Polsce, jak i orientacji politycznej na dobre rządzenie, zgodnie z którą PoSW jest tworzone według najlepszych wzorców zarządzania publicznego, kanonów postępowania w polityce publicznej i standardów stanowienia prawa.

Omówiony wyżej model dochodzenia do prawa o szkolnictwie wyższym jako kluczowego rezultatu polityki publicznej w tym sektorze (a także instrumentu tej polityki) wiązał się z potrzebą analizy dwóch procesów: procesu programowania strategicznego oraz procesu ustawodawczego. Empiryczna egzemplifikacja debaty wokół reformowania szkolnictwa wyższego w wymiarze strategicznym objęła najważniejsze 
dokumenty wytyczające - na gruncie polityki rozwoju - kierunki rozwoju szkolnictwa wyższego (w tym uniwersytetów) w polityce unijnej i krajowej. Choć na lokalną (polską) politykę szkolnictwa wyższego przez ponad dwie i pół dekady wpływ miały transnarodowe trendy konwergencji systemów narodowych, co doskonale opisał Dominik Antonowicz (2015), to członkostwo Polski w Unii Europejskiej i związane $\mathrm{z}$ tym wsparcie finansowe $\mathrm{w}$ znacznie większym stopniu oddziaływały na modelowanie krajowej polityki publicznej.

$\mathrm{W}$ latach 90. XX w. wiodące traktaty europejskie, w sensie formalnoprawnym, wyłączały spod kompetencji wspólnotowych/unijnych sferę edukacji, pozostawiając państwom członkowskim odpowiedzialność za ich systemy edukacyjne, stąd szkolnictwo wyższe nie było przedmiotem ściśle określonej polityki europejskiej. Już wtedy jednak Wspólnota uświadamiała sobie rolę dyskusji o uniwersytetach i instytucjach szkolnictwa wyższego w kontekście politycznym i ekonomicznym. Czołowe strategie unijne - strategia lizbońska (2000-2010) i jej następczyni „Europa 2020" - wyznaczyły główne kierunki reform w UE, a liczne dokumenty Komisji Europejskiej wskazywały konkretne cele modernizacji europejskiego szkolnictwa wyższego (w tym budowy Europejskiego Obszaru Szkolnictwa Wyższego i Europejskiej Przestrzeni Badawczej).

Rekonstrukcja kursu polityki szkolnictwa wyższego pod wpływem polityki ponadnarodowej umożliwiła postawienie tezy o translacji (a nie transferze) polityki, czyli pewnej adaptacji określonych celów do polskich warunków, gdyż odbyło się to bez radykalnego podniesienia nakładów na szkolnictwo wyższe. Przed wejściem w struktury unijne trudno mówić o profesjonalnym programowaniu strategicznym odnoszonym do szkolnictwa wyższego (pojawiła się strategia do 2010 r., ale jej nie przyjęto). Przez pierwsze lata po akcesji do Unii Europejskiej kwestia przyszłości szkolnictwa wyższego w Polsce i jego roli w rozwoju kraju była praktycznie nieobecna w dokumentach strategicznych o charakterze horyzontalnym. Dopiero wraz z profesjonalizującym się coraz bardziej podejściem państwa do prognozowania i planowania rozwoju, zainicjowanego regularnym dofinansowaniem $\mathrm{z}$ budżetu UE w latach 2007-2013, stopniowo wyłaniało się znaczenie szkolnictwa wyższego i nauki dla rozwoju społeczno-gospodarczego oraz wynikająca $z$ tego potrzeba jego modernizacji. Analiza krajowych strategii i programów z lat 1990-2015 (zarówno przyjętych, jak i projektów) dowiodła ewolucji myślenia strategicznego o szkolnictwie wyższym w Polsce. Uwzględniając jednocześnie procesy legislacyjne w tym obszarze, widać, że nie doszło do ich sprzężenia z działalnością strategiczną. Można mówić o początkowym zaniechaniu działań strategicznych w stosunku do szkolnictwa wyższego (etap braku działań strategicznych 1990-2005), następnie o ich opóźnieniu (etap działań prestrategicznych 2005-2011) i wreszcie o odwróceniu 
kolejności działań w kształtowaniu krajowej polityki szkolnictwa wyższego (etap działań pozastrategicznych 2011-2015).

Na projektowanie prawa o szkolnictwie wyższym wpływ miały również odnotowywane przez znawców prawodawstwa niedostatki rodzimego procesu stanowienia prawa i warsztatu legislacyjnego w tzw. fazie rządowej, w tym słabości procesu konsultacyjnego. Wymiar legislacyjny (ustawodawczy) przeanalizowany został w odniesieniu do najważniejszych ustaw z zakresu szkolnictwa wyższego i ich nowelizacji. Pozwoliło to na wyróżnienie chronologicznie trzech okresów: 1990-2005, 2005-2011, 2011-2015 - również w odniesieniu do przebiegu rosnącego angażowania się interesariuszy środowiskowych w proces ustawodawczy w ramach konsultacji społecznych.

Z każdym etapem prac nad prawem rosła liczba uwag dotyczących techniki prawodawczej, co świadczy o zwiększającej się świadomości programotwórczej i prawotwórczej interesariuszy (szczególnie wewnętrznych, środowiskowych). W licznych opiniach, uchwałach i stanowiskach formułowanych w ciągu 25 lat w ramach debaty ustawodawczej we wszystkich trzech okresach najwyraźniej artykułowano zarzuty dotyczące braku dalekowzrocznej polityki państwa wobec szkolnictwa wyższego przejawiającej się niewykorzystaniem strategii szkolnictwa wyższego. Krytykowano też zwłokę w uchwaleniu prawa o szkolnictwie wyższym (15 lat po pierwszej potransformacyjnej ustawie), a następnie zwiększoną częstotliwość nowelizacji oraz zbyt dużą szczegółowość regulacji o charakterze ustawowym. Przez dwie i pół dekady pomimo tych głosów i podejmowanych przez MNiSW aktywności w kierunku opracowania strategii (głównie w latach 2010-2015) nie udało się zastosować owej prostej, a zalecanej przez badaczy i praktyków sekwencji działań: najpierw strategia, potem prawo. Nie udało się również zaprojektować ustawy, która nie byłaby efektem korygowania prawa zamiast jego racjonalnego i kompleksowego zaprojektowania w duchu opartej na dowodach i wyznaczanej wizją przyszłości strategii rozwoju. Zaprezentowana w dużym skrócie historia reformowania szkolnictwa wyższego w Polsce, obejmująca strategiczne i legislacyjne działania państwa (tabela 1), ilustruje pewien postęp $\mathrm{w}$ formułowaniu polityki tego sektora, dowodzi jednocześnie zmarnowanej szansy na optymalne jej zaprojektowanie i wdrożenie.

Analiza kursu reform skoncentrowana na wiodących kierunkach zmian legislacyjnych w latach 1990, 2005 i 2011 dostarcza ciekawych wniosków na temat stopnia interwencjonizmu państwowego w funkcjonowanie szkolnictwa wyższego (tabela 2). Ustawa z 1990 r. przywracająca uczelniom autonomię jest przykładem symbolicznego uwolnienia tego sektora spod władz państwowych (partyjnych) i oddania go w ręce wolnego rynku. Prawo o szkolnictwie wyższym z 2005 r. jest efektem niezadowolenia z konsekwencji tego posunięcia, a jednocześnie - w kontekście wejścia do Unii Europejskiej - umożliwienia uczelniom oddolnego dostosowania się do zmian dyktowanych 
przez proces boloński. Natomiast nowelizacja ustawy w 2011 r., akcentująca znaczenie ewaluacji zewnętrznej wyników naukowych, może stanowić dowód na swego rodzaju powrót do odgórnej kontroli aktywności jednostek naukowych i uczelni. Oczywiście przedstawione tu konkluzje nie wyczerpują meritum reform, mają jedynie za zadanie pokazać, że ewolucja $\mathrm{w}$ reformowaniu sprzęga się z rosnącą ingerencją państwa, co odpowiada globalnym tendencjom w reformowaniu sektora szkół wyższych i nauki.

Tabela 1. Szkolnictwo wyższe w dokumentach strategicznych i jego reformy (1990-2015)

\begin{tabular}{|c|c|c|c|}
\hline & $\begin{array}{l}\text { Etap braku działań } \\
\text { strategicznych } \\
(1990-2005)\end{array}$ & $\begin{array}{l}\text { Etap działań prestrategicznych } \\
\qquad(2005-2011)\end{array}$ & $\begin{array}{l}\text { Etap działań pozastrategicznych } \\
\qquad(2011-2015)\end{array}$ \\
\hline $\begin{array}{l}\text { Strategie } \\
\text { ogólnokrajowe } \\
\text { i inne } \\
\text { dokumenty }\end{array}$ & $\begin{array}{l}\text { Brak ogólnokrajowego } \\
\text { systemu programowania } \\
\text { strategicznego }\end{array}$ & $\begin{array}{l}\text { Kwestia szkolnictwa wyższego } \\
\text { zdawkowo potraktowana } \\
\text { w ogólnokrajowych dokumentach } \\
\text { strategicznych } \\
\text { Kwestia szkolnictwa obecna } \\
\text { w Strategii rozwoju edukacji } \\
\text { na lata 2007-2013 oraz } \\
\text { Programie Operacyjnym Kapitał } \\
\text { Ludzki }\end{array}$ & $\begin{array}{l}\text { Kwestia szkolnictwa wyższego } \\
\text { uwzględniona w ramach } \\
\text { zintegrowanego systemu } \\
\text { zarządzania strategicznego } \\
\text { - w Długookresowej Strategii } \\
\text { Rozwoju Kraju, Średniookresowej } \\
\text { Strategii Rozwoju Kraju } \\
\text { (SRK 2020) oraz Strategii } \\
\text { Rozwoju Kapitału Ludzkiego }\end{array}$ \\
\hline $\begin{array}{l}\text { Reformy } \\
\text { szkolnictwa } \\
\text { wyższego } \\
\text { a strategie } \\
\text { rozwoju } \\
\text { szkolnictwa } \\
\text { wyższego }\end{array}$ & $\begin{array}{l}\text { Wdrożenie pierwszej } \\
\text { potransformacyjnej reformy } \\
\text { szkolnictwa wyższego } \\
\text { Ustawą o szkolnictwie } \\
\text { wyższym z } 1990 \text { r. } \\
\text { Opracowanie, ale } \\
\text { nieprzyjęcie „Strategii } \\
\text { rozwoju szkolnictwa } \\
\text { wyższego w Polsce } \\
\text { do roku 2010” }\end{array}$ & $\begin{array}{l}\text { Wdrożenie drugiej } \\
\text { potransformacyjnej reformy } \\
\text { ustawą Prawo o szkolnictwie } \\
\text { wyższym z } 2005 \text { r. i prace nad jej } \\
\text { nowelizacją } \\
\text { Opracowanie w } 2010 \text { r. dwóch } \\
\text { konkurujących propozycji } \\
\text { strategii rozwoju szkolnictwa } \\
\text { wyższego: } \\
\text { - Strategia rozwoju szkolnictwa } \\
\text { wyższego w Polsce do } \\
\text { 2020 roku (projekt ministerialny } \\
\text { autorstwa Ernst\& Young oraz } \\
\text { IBNGR) } \\
\text { - Strategia rozwoju szkolnictwa } \\
\text { wyższego 2010-2020 (projekt } \\
\text { środowiskowy autorstwa FRP/ } \\
\text { KRASP) }\end{array}$ & $\begin{array}{l}\text { Wdrożenie trzeciej } \\
\text { potransformacyjnej reformy } \\
\text { nowelizacją Prawa o szkolnictwie } \\
\text { wyższym z } 2011 \text { r. i dalszą } \\
\text { nowelizacją PoSW } \\
\text { Opracowanie i przyjęcie w } 2015 \text { r. } \\
\text { Programu rozwoju szkolnictwa } \\
\text { wyższego i nauki na lata } \\
2015-2030\end{array}$ \\
\hline
\end{tabular}

Źródło: opracowanie własne na podstawie Dziedziczak-Foltyn (2017: 107).

Po 2015 roku, wraz ze zmianą obozu politycznego w Polsce, rozpoczęto prace nad całkiem nową ustawą, tzw. Ustawą 2.0 (nazywaną też Konstytucją dla nauki). Obowiązująca od 14 lutego 2017 r. aktualizacja Strategii Rozwoju Kraju 2020, czyli Strategia na rzecz odpowiedzialnego rozwoju do roku 2020 (z perspektywą do 2030 r.) rzeczywiście podkreśla znaczenie szkolnictwa wyższego i sygnalizuje plany reform².

2 https://www.miir.gov.pl/media/48672/SOR.pdf, dostęp 23.04.2018. 
Trudno jednak wnioskować na podstawie lektury SOR o realnej wadze tego sektora dla rządzących, skoro nie jest znany na ten moment nowy system dokumentów strategicznych, który wykazywałby (lub nie) zgodność w myśleniu systemowym o potencjale szkół wyższych. Problematyczna wydaje się też kwestia obowiązywania strategii rozwoju szkolnictwa wyższego.

Tabela 2. Kluczowe kierunki reform a interwencjonizm państwa (1990-2015)

\begin{tabular}{|l|l|l|l|}
\cline { 2 - 4 } \multicolumn{1}{c|}{} & \multicolumn{1}{|c|}{1990} & \multicolumn{1}{c|}{2005} & \\
\hline $\begin{array}{l}\text { Pragmatyzacja } \\
\text { celów }\end{array}$ & $\begin{array}{l}\text { Przywrócenie po czasach PRL } \\
\text { autonomii instytucjonalnej } \\
\text { szkołom wyższym (leseferyzm } \\
\text { w obszarze szkolnictwa } \\
\text { wyższego) }\end{array}$ & $\begin{array}{l}\text { Europeizacja szkolnictwa } \\
\text { wyższego (w dużym stopniu } \\
\text { oddolne dostosowywanie } \\
\text { się uczelni do procesu } \\
\text { bolońskiego w obszarze } \\
\text { kształcenia) }\end{array}$ & $\begin{array}{l}\text { Wprowadzenie regularnej } \\
\text { dnternacjonalizacja } \\
\text { działania }\end{array}$ \\
\hline $\begin{array}{l}\text { Ewaluacja } \\
\text { wyników }\end{array}$ & $\begin{array}{l}\text { oceny wyników pracowników } \\
\text { oraz wzmocnienie } \\
\text { kompleksowej działalności } \\
\text { naukowej i badawczo- }\end{array}$ \\
\hline
\end{tabular}

Źródło: opracowanie własne na podstawie Dziedziczak-Foltyn (2017: 107).

Jarosław Gowin, minister nauki i szkolnictwa wyższego, ogłosił 9 września 2016 r. nową strategię dla nauki i szkolnictwa wyższego - Strategię na rzecz doskonałości naukowej, nowoczesnego szkolnictwa wyższego, partnerstwa z biznesem i społecznej odpowiedzialności nauki (na stronie MNiSW udostępniono 16-stronicową prezentację dokumentu) ${ }^{3}$, której jednym z trzech filarów jest Konstytucja dla nauki określająca zmiany systemowe w szkolnictwie wyższym.

Teoretycznie zatem strategia poprzedza zaprojektowanie prawa, nie przypomina ona jednak typowego dokumentu strategicznego i powstała przed przyjęciem najważniejszego obecnie krajowego dokumentu strategicznego - SOR. Inna kwestia to upolitycznienie ( $w$ znaczeniu upartyjnienia) obecnie powstającego systemu programowania strategicznego i związane z tym konsekwencje braku ciągłości dla polityki publicznej (koszty finansowe i społeczne). Znacznie zmieniła się natomiast praktyka

3 http://www.nauka.gov.pl/aktualnosci-ministerstwo/nowa-strategia-dla-nauki-i-szkolnictwa-wyzszego.html, dostęp 23.04.2018. 
stanowienia prawa na szczeblu rządowym (resortowym) w przypadku Ustawy 2.0, gdyż po raz pierwszy w historii reform tego sektora MNiSW przeprowadziło konsultacje zakrojone na tak szeroką skalę i do tego kilkuetapowe (faza konceptualna związana z zapoczątkowaniem zmian - prekonsultacje oraz faza konsultacyjna w trakcie przygotowywania projektu ustawy - formalne konsultacje publiczne). Faza prekonsultacji objęła zorganizowanie konkursu na koncepcję założeń do projektu ustawy, w ramach którego wyłonione trzy zespoły przeprowadziły konsultacje wewnętrzne, oraz cykl dziewięciu konferencji programowych zwieńczonych Narodowym Kongresem Nauki, na które łącznie zarejestrowało się ponad 8 tys. osób. W trakcie konsultacji publicznych projektu Ustawy 2.0. zebrano 2957 uwag, których samo zestawienie w jednym dokumencie zajęło 842 strony ${ }^{4}$. Można na tej podstawie postawić tezę o dużym stopniu konsultatywności w reformowaniu szkolnictwa wyższego (i nauki, gdyż Ustawa 2.0 łączy regulacje dotyczące dwóch obszarów, dotąd objętych odrębnymi ustawami), aczkolwiek sama skala konsultacji nie przesądza jeszcze o lepszej jakości stanowionego w ten sposób prawa. Najważniejszym jej aspektem będzie kwestia realnego wpływu interesariuszy na ostateczny kształt ustawy (Dziedziczak-Foltyn, 2018).

\section{Sztuka reformowania a standardy polityki publicznej}

W poniższym fragmencie analizuję reformy szkolnictwa wyższego, korzystając z koncepcji reformowania, które zalecały organizacje międzynarodowe (Bank Światowy, OECD). Znane są one pod nazwą ekonomii politycznej reform (EPR). Bank Światowy w swoim podejściu uwypukla następujące aspekty reform: procesowe, selektywne, czasowe i sekwencyjne. OECD (2009) w jednym z raportów przedstawia 20 studiów reform strukturalnych w wybranych krajach w latach 2007-2008, w których wyróżnia kluczowe determinanty sukcesu reform:

1) czynniki polityczne (cykl wyborczy, polityczna opozycja, zaangażowanie różnych poziomów władzy rządowej),

2) czynniki ekonomiczne (koniunktura, problemy fiskalne, rynek pracy, liberalizacja rynku),

3) czynniki związane z czasem, tempem i kolejnością reform oraz ich zasięgiem,

4) kondycja sfery komunikacji, konsultacji i przywództwa,

5) obecność dialogu z aktualnymi i potencjalnymi oponentami.

4 https://legislacja.rcl.gov.pl/docs//2/12303102/12458887/12458888/dokument334132.pdf, dostęp 30.03.2018. 
Z kolei publikacja OECD (2010) daje wskazówki pomagające w „uczeniu się polityki” od innych krajów:

1) powiązanie silnych finansów publicznych z postępem reformy,

2) dysponowanie mandatem wyborczym dla reformy,

3) skuteczna komunikacja,

4) oparcie projektu reformy na rzetelnych badaniach i analizie,

5) posiadanie odpowiednich instytucji dla pomyślnego przejścia od etapu decyzji do etapu wdrożenia,

6) czas,

7) przywództwo,

8) przeprowadzenie kilku prób,

9) włączenie w reformę jej oponentów zamiast ignorowanie ich sprzeciwu,

10) rozważenie kwestii, czy, kiedy i w jaki sposób zrekompensować szkody osobom, które ucierpiały w wyniku reformy (Dziedziczak-Foltyn, 2017: 247-248).

Powyższa formuła ekonomii politycznej reform umożliwia ocenę dotychczasowych reform szkolnictwa wyższego w Polsce. Porównanie trzech znaczących momentów w historii reformowania (1990, 2005 i 2011) oraz prac nad Ustawą 2.0 pokazuje zarówno ewolucję w podejściu do stosowania owych zasad, jak i niedostatki „sztuki reformowania" (tabela 3).

Tabela 3. Wybrane zasady EPR a reformowanie szkolnictwa wyższego w Polsce

\begin{tabular}{|l|c|c|c|c|}
\hline \multicolumn{1}{|c|}{ Zasady EPR } & 1990 & 2005 & 2011 & 2018 \\
\hline Mandat polityczny/wyborczy dla reformy & + & + & + & $?$ \\
\hline Wyraźne przywództwo w procesie reformowania & - & - & + & $?$ \\
\hline Rzetelna analiza i diagnoza problemów & - & - & + & + \\
\hline Odpowiednia logistyka reformy (czas, kolejność) & - & - & $-/+$ & + \\
\hline Jasna komunikacja intencji, celów i zadań reform & - & - & + & + \\
\hline Relacje z interesariuszami oparte na dialogu & - & $-/+$ & + & $+?$ \\
\hline Niezbędne wsparcie finansowe reformy & - & - & - & - \\
\hline
\end{tabular}

Źródło: opracowanie własne.

Powyższe zestawienie wybranych zasad ekonomii politycznej reform i kolejnych reform szkolnictwa wyższego w Polsce dowodzi uczenia się polityki przez kolejnych decydentów. Jest to jednak uczenie się dość wolne i niedostateczne albo nieefektywne.

Zasadniczym celem pierwszej ustawy potransformacyjnej było nadanie uczelniom autonomii i stworzenie warunków dla procesów rynkowych w szkolnictwie wyższym (prywatyzacji polegającej na możliwości otwierania szkół niepublicznych i pobierania opłat za kształcenie w trybie zaocznym na uczelniach publicznych). O ile w $1990 \mathrm{r}$. 
państwo miało polityczne poparcie dla ówczesnej reformy, to bardziej priorytetowe problemy społeczne związane ze skutkami transformacji (bezrobocie, zła sytuacja finansów publicznych) przesądziły o bardzo liberalnej, biernej polityce szkolnictwa wyższego albo wręcz o braku rzeczywistej polityki w tamtym okresie.

Negatywne konsekwencje tego stanu rzeczy (umasowienie, niska jakość kształcenia) dostrzeżono po 12 latach, gdy z racji akcesji do Unii Europejskiej pojawiła się potrzeba dostosowania do wymogów procesu bolońskiego. Dla Prawa o szkolnictwie wyższym z 2005 r. również było polityczne poparcie ( $w$ tym prezydenta Aleksandra Kwaśniewskiego), ale poza pewnymi próbami dialogu z najważniejszymi interesariuszami szkolnictwa wyższego (przede wszystkim Konferencją Rektorów Akademickich Szkół Polskich oraz Radą Główną Szkolnictwa Wyższego) nie były spełnione pozostałe kryteria sztuki reformowania. W opinii A. Antonowicza (2015: 287-288) na mocy ustawy z 2005 r. nastąpiła legitymizacja najważniejszych instytucjonalnych interesariuszy szkolnictwa wyższego, co doprowadziło do jednoznacznego zdefiniowania głównych jej aktorów, a tym samym instytucjonalizacji polityki szkolnictwa wyższego w Polsce.

Największy postęp w zakresie stosowania zasad ekonomii politycznej reform przyniosła tzw. reforma Kudryckiej. Prace nad ustawą z 2011 r. charakteryzowały się nie tylko mandatem politycznym dla reformy (neoliberalne reformy wprowadzał neoliberalny rząd), ale też wyraźne było przywództwo w procesie reformowania przypisywane minister Barbarze Kudryckiej. Reformatorzy skorzystali też ze wskazówek w zakresie analizy i diagnozy problemów, gdyż w latach poprzedzających wdrożenie reformy powstało wiele ekspertyz i opracowań służących owej diagnozie i identyfikacji problemów ( $\mathrm{w}$ tym zlecony firmom zewnętrznym projekt strategii rozwoju szkolnictwa wyższego, równolegle powstał projekt środowiskowy firmowany przez KRASP). MNiSW zastosowało też rozsądną logistykę, dzieląc przygotowanie ustawy na kilka etapów (projekt założeń reformy, pakiet założeń reformy Partnerstwo dla wiedzy, założenia do nowelizacji ustawy oraz projekt ustawy). Jednocześnie nie zrealizowano innej logicznej zasady co do kolejności działań i uchwalono ustawę bez przyjętej strategii rozwoju szkolnictwa wyższego, która winna ją poprzedzać. Ministerstwo podejmowało próby komunikacji intencji, celów i zadań, gdyż były one wskazywane $w$ licznych dokumentach oraz medialnie. Obecne były dążenia do nawiązywania relacji z interesariuszami (spotkania i konferencje organizowane przez MNiSW), o czym świadczy widoczny w debacie publicznej proces konsultacji społecznych. W całym omawianym procesie legislacyjnym towarzyszącym ustawie z 2011 r. wyraźne były jednak pewne niedoskonałości tej komunikacji - np. konsultacje społeczne przypadające na okres wakacji lub zbyt krótkie, brak sprawozdań czy jasnej informacji publicznej o aktualnym przebiegu konsultacji na stronie MNiSW, brak 
publicznej reakcji ministerstwa na oficjalnie zgłaszane uwagi organizacji związanych ze szkolnictwem wyższym. Niezależnie od pozytywnie ocenionych głównych aspektów formalnych reformy z 2011 r., trzeba zauważyć, że nie zapewniono jej niezbędnego wsparcia finansowego, co znacznie utrudniło realizację celów.

Niesfinalizowana jeszcze Ustawa 2.0 jest przykładem reform najbardziej zbliżonym do omawianego wzorca reformowania, jednak i w jej przypadku trudno mówić o rzetelnie odrobionej lekcji z reformowania i kształtowania polityki szkolnictwa wyższego. Przede wszystkim dlatego, że rząd nie zgodził się na ustawową gwarancję wzrostu nakładów na szkolnictwo wyższe i naukę (Dziedziczak-Foltyn, 2018b). Problematyczna jest kwestia mandatu politycznego dla reformy powiązanego z przywództwem w procesie reformowania. O ile przywództwo z całą pewnością można przypisać szefowi resortu i jednocześnie wiceprezesowi Rady Ministrów Jarosławowi Gowinowi, to nieco skomplikowała się u progu etapu parlamentarnego prac nad Ustawą 2.0 kwestia mandatu polityczno-partyjnego. Krytyczna postawa przedstawicieli rządzącej partii Prawo i Sprawiedliwość wobec projektu ustawy (pomimo poparcia reformy przez prezesa PiS Jarosława Kaczyńskiego) także nie pozwala na wniosek o zdecydowanym mandacie politycznym dla tej reformy (Dziedziczak-Foltyn, 2018a). Zintensyfikowana na etapie prac sejmowych krytyka Ustawy $2.0 \mathrm{w}$ debacie publicznej (i liczne w Polsce protesty przeciw niej ${ }^{5}$ ) podważają tezę o spełnieniu warunku dialogu z interesariuszami. Weryfikacja tej tezy wymaga szczegółowej analizy zmian wprowadzonych $\mathrm{w}$ zapisach ustawy w wyniku konsultacji na etapie rządowym i parlamentarnym.

\section{$* * *$}

Historia reformowania szkolnictwa wyższego w Polsce to także historia ewoluowania polityki szkolnictwa wyższego (w znaczeniu polityki publicznej). Należy docenić tę ewolucję polegającą na coraz większym zbliżaniu się do standardów reformowania uznanych za optymalne dla powodzenia reform i polityki. Stały niepokój budzi jednak fakt niezrozumienia przez decydentów, jak ważne jest sfinansowanie reform. Najlepsze bowiem rozwiązania, przy zaawansowanej nawet sztuce reformowania, bez zapewnionych na nie środków nie będą mogły być optymalnie zastosowane. To lekcja płynąca z doświadczeń innych krajów i kwestia stale podnoszona w krajowej debacie publicznej, zatem dziwi tak stabilna przez prawie trzy dekady ignorancja rządzących (niezależnie od partii) dla najważniejszej zasady ekonomii politycznej reform. Przykład Ustawy 2.0 pokazuje dodatkowo, jak trudno uzyskać efekt dialogu

\footnotetext{
5 http://naukawpolsce.pap.pl/aktualnosci/news\%2C30078\%2Cgowin-ustawa-o-szkolnictwie-wyzszym-jest-dobrym-kompromisem.html, dostęp 29.06.2018.
} 
z interesariuszami pomimo włożonego w komunikację i konsultacje wysiłku. Najlepiej przygotowana pod tym względem (spośród dotychczasowych) reforma szkolnictwa wyższego paradoksalnie spotkała się z najbardziej zintensyfikowaną krytyką i oporem. Niewątpliwie jest to temat wart dalszych pogłębionych analiz, również z perspektywy nauk o polityce publicznej.

\section{Bibliografia}

Antonowicz, A. (2015). Między siła globalnych procesów a lokalna tradycją. Polskie szkolnictwo wyższe w dobie przemian. Toruń: Wydawnictwo Naukowe Uniwersytetu Mikołaja Kopernika.

Dziedziczak-Foltyn, A. (2011). Imperatyw rozwoju a kondycja myślenia strategicznego o polskim szkolnictwie wyższym (i nauce) w dobie transformacji systemowej. Nauka i Szkolnictwo Wyższe, nr 2(38): 88-106.

Dziedziczak-Foltyn, A. (2017). Reforma szkolnictwa wyższego w Polsce $w$ debacie publicznej. Bilans dyskusji o uniwersytetach (1990-2015). Łódź: Wydawnictwo Uniwersytetu Łódzkiego.

Dziedziczak-Foltyn, A. (2018a). Konsultatywność w projektowaniu reformy szkolnictwa wyższego w Polsce na przykładzie Ustawy 2.0. Nauka i Szkolnictwo Wyższe, w druku.

Dziedziczak-Foltyn, A. (2018b). Ocena skutków projektu Ustawy 2.0: konsekwencje prawne, społeczne, finansowe, gospodarcze, kulturowe i polityczne, ekspertyza dla Biura Analiz Sejmowych przygotowana w imieniu Polskiego Towarzystwa Socjologicznego, http:// pts.org.pl/wp-content/uploads/2018/04/Ocena_skutk\%C3\%B3w_projektu_Ustawy_2.0_ POLSKIE_TOWARZYSTWO_SOCJOLOGICZNE_DZIEDZICZAK-FOLTYN-2018-04-16. pdf, dostęp 25.04.2018.

Fundacja Rektorów Polskich (2012). Propozycja warunków przyznawania uprawnień do nadawania stopnia $w$ dziedzinie nauk spolecznych $w$ zakresie nauk o polityce publicznej, http:// www.frp.org.pl/pliki/054325. JPG, dostęp 2.04.2018.

Lindvall, J. (2017). Reform Capacity. Oxford: Oxford University Press.

OECD (2009). The Political Economy of Reform. Lessons from pensions, product markets and labour market in ten OECD countries, Chapter 2 Key determinants of successful structural reform, http://www.oecd.org/site/sgemrh/46190166.pdf, dostęp 30.03.2018.

OECD (2010). Wcielanie reformy $w$ życie. Projekty strukturalne w okresie kryzysu, http://www. oecd.org/fr/sites/reussirlareforme/46269269.pdf, dostęp 30.03.2018.

Szarfenberg, R. (2013). Nauki o i dla polityki publicznej: podejścia teoretyczno-metodologiczne, w: Wojciuk, A. (red.). Analiza polityki publicznej. Podejścia teoretyczno-metodologiczne. Warszawa: Instytut Badań Edukacyjnych: 26.

Szarfenberg, R. (2016). Polityka publiczna - zagadnienia i nurty teoretyczne. Studia z Polityki Publicznej, nr 1(9): 48.

Wilkin, J. (red.) (2013). Jakość rządzenia w Polsce. Jak ją badać, monitorować i poprawiać? Warszawa: Wydawnictwo Naukowe Scholar. 
Woźnicki, J. (2012). Nowa dyscyplina - „nauki o polityce publicznej” usytuowana w dziedzinie nauk społecznych. Nauka, nr 1: 142.

Woźnicki, J. (2015). Nauki o polityce publicznej - cztery lata rozwoju w symbiozie z politologią. Politeja, nr 4(36): 12.

Zybała, A. (2013). Państwo i społeczeństwo $w$ działaniu. Polityki publiczne wobec potrzeb modernizacji państwa i społeczeństwa. Warszawa: Difin. 
